\title{
From the Construction of Hegemony to State Crisis: Political Power and Social Media in Turkey
}

\author{
By Utku Uraz Aydin ${ }^{*}$ \\ Can Guler
}

The Justice and Development Party (AKP) came to power promising democratization and economic prosperity. It successfully gained support from different fractions of capital, including religious groups. After a relatively democratic period, the party started a hegemonic project based on an authoritarian populism and conservative identity. As the government control over traditional media increased, social media became a tool for political debates. When the government passed a law restricting internet access to a degree we might call "the moralization of the digital public sphere", tens of thousands of young protesters marched through the streets of Istanbul. The same crowd showed up at the Gezi Protests again pushing the government into taking more radical measures. This study aims to analyze different stages of the government's intervention with social media, based around the concept of hegemony. In this regard, we examined the cases which the government criminalizes and punishes opponents through the opinions expressed.

Keywords: hegemony, internet censorship, social media, Turkey, The Justice and Development Party

\section{Introduction}

With the help of the anti-globalization movement and the social forums; and after the wave of uprisings, occupations and resistance acts we have been seeing in the Arab world, the US, Spain, Greece and Turkey since 2010, that the potential social media has intrigued the attention of communication scientists; and it has been a research topic for them that cannot be overlooked ever since (Çoban, 2014; Della Porta \& Tarrow, 2005; Van De Donk, Loader, Nixon, \& Rucht, 2004; Gerbaudo, 2014; Tüfekçi \& Wilson, 2012). By helping citizens coordinate their actions and creating an opportunity for them to react against the oppressing practices the state performs, or the destruction the Capital causes on the social sphere and the environment; Internet and the social media work as a tool to communicate, interact and organize in order to surpass the boundaries of geography and time, and also escape from the state's control. Parallel to the increasing importance of social media however, the control of social media is becoming more and more important for the governments, especially for authoritarian regimes like Turkey under the rule of the Justice

\footnotetext{
* PhD Graduate \& Research Assistant, Faculty of Communication, Marmara University, Turkey.

${ }^{\dagger}$ Research Assistant, Faculty of Communication, Marmara University, Turkey.
} 
and Development Party (AKP). Therefore, Turkey's policies on social media can be interpreted as legal forms of monitoring and banning, as well as punishment. In this study, we will focus on how the AKP operationalized their implementations towards the social media in order to bring their hegemonic project into life ${ }^{1}$.

By examining the securitarian reconstruction of the state's institutional architecture (through the case of the control over social media) in the context of the hegemonic project, this article focuses on the strategic-relational theoretical framework. This framework, on the contrary to the state-centric approach, does not consider the state an institution autonomous from society and from the struggles between political-social forces. In contrast to the reductionist classist approach it does not examine the state as a simple instrument of a class or class fraction. From a materialist perspective, it accepts the state as a social relation. It suggests that the construction of the state can only be understood within wider socio-political power relations. It presents it as a process which the state transforms society while the struggles of the social forces transform the state. Therefore, the state should be considered the base, the source and also the product of the strategies developed by different socialpolitical actors in order to maintain or transform the current state order. These relations between social-political actors can be analyzed in the framework of the hegemonic projects which are built in connection with capital accumulation strategies. Hegemonic projects tend to need of approval and consent of the subaltern classes while creating a power block that brings the different fractions of the capital together. In this regard, they usually have to cover noneconomical issues as well, such as political, social or cultural -religious or moral for example- issues, in order to appeal the subaltern (Akça, 2010; Akça, Bekmen \& Özden, 2014; Jessop, 2008).

This study will classify the state's practices to control over and via social media from 2007 to 2015. This classification will be discussed within the framework of the hegemonic project which was shaped by the AKP and relates (whether conflicts and/or alliances) to the acting forces such as Gezi Resistance, Gülen Movement and partially the Kurdish Movement ${ }^{2}$ (and the social forces they are based on).

\footnotetext{
${ }^{1}$ We use the term "Hegemonic Project" as Bob Jessob defines it based on Italian Marxist Antonio Gramsci's theoretical legacy: Hegemonic projects are national-popular programs of action that manufacture and mobilize the active consent and support of the subordinate social forces as well as the unity of the power bloc (i.e. the dominant classes) in pursuit of the long term interests of the hegemonic class (Jessop, 2008, p. 279).

${ }^{2}$ In May 2013, after long going non-official meetings, the beginning of the negotiations between the Turkish state and Abdullah Ocalan, the imprisoned leader of the Kurdish movement, was announced. However, the truce was broken in July 2015, as the President Recep Tayyip Erdoğan and the AKP switched back to a nationalist-statist position and the armed conflicts started again. These turn of events occured after the date range our research covers and they marked the start of a new era of authoritarianism and militarization in state structure. This also initiated another wave of repressive interventions on social media.
} 


\section{AKP and the Conservative Populist Hegemony}

One year after Turkey was shaken by a deep economic crisis, the Justice and Development Party (AKP) came to power in 2002. While the AKP received $34.3 \%$ of the votes, all the other parties -be it center-right or centerleft, nationalist and extremist Islamic right-wing parties- except for the CHP who is also the founder of the Republic of Turkey, failed to bypass the $10 \%$ election threshold in order to be present in the parliament, and that includes the three parties who were the coalition partners to the previous government. In fact, this sudden collapse in the current political spectrum was the final phase of a very long political hegemony crisis.

\section{A Brief History of a Long Hegemony Crisis}

The roots of this crisis, in fact, extend far back to another crisis that occurred in the late seventies. At the end of the seventies, three separate crises arose (1) The crisis of the capital accumulation regime based on the import substitution industrialization; (2) the crisis of political representation that emerged as a reaction from people who did not find the traditional parties that were supposed to represent them convincing anymore; (3) the crisis of hegemony that surfaced when the bourgeoisie failed to manufacture the consent of the subaltern classes. These three crises merged and formed a full fledged, organic crisis (Akça, 2009). The accumulation regime based on exports, and the hegemonic project based on the transformation of the state and the nation -which were also implemented during the oppression period of September, 12, 1980 Military Coup- were successfully put into effect once again, in order to overcome this troublesome situation. This went on until the very end of the eighties. Neoliberalism declared its domination by reforming the state's institutional architecture, restructuring the economic space, weakening the labor movement both union-wise and politically, creating an authoritarian market society and individuals (consumerist and competitive) suitable for this society (Boratav, 2005; Özkazanç, 2005). However, with the dissolution of the New Right project, which was actually a nationalistconservative-liberal coalition embodied in the Motherland Party (ANAP), a political hegemony crisis would arise and continue until the AKP came to power in 2002. There are several reasons why there was no political actor in the last decade of the $20^{\text {th }}$ century to represent the interests of the bourgeoisie and implement the neoliberal accumulation strategy while maintaining "stability" and manufacturing the consent of the subaltern, thus the political representation crisis occurred. But the most important one-and the one that triggered/reinforced the rest- was the fact that the New Right project was highly exclusive both politically and economically, and that it failed to receive consent from the vast majority of people to carry out the neoliberal economic policies and constitute an authoritarian state design necessary to perform them.

The initial results from the destruction caused by Neoliberalism began to show themselves as the labor movement was reborn in the 80s and 90s. On the 
other hand, the Kurdish national movement also began the armed struggle and strengthened itself, so the consisting of a civil war caused a gradual increase in the political power of the Turkish Armed Forces (Öngen, 2002; Balta Paker, 2010). The decline in the class consciousness and sense of belonging to a class played an important role in the growing prominence of religious and cultural identity. The Islamic-conservative movement, which was excluded from the power block during the western authoritarian modernization era; gained increasingly radicalized power and stepped in the politics as an autonomous actor; by legitimizing itself, as the conservative values that were being consecrated in accordance with the New Right's understanding of the world. The Turkish-Islamic synthesis was articulated to the state's official ideology under the military regime. Winning the municipalities in metropolises and being a coalition partner to the government in 1995, the Islamic Refah Party (Welfare Party) fell from power as a result of the memorandum by the military in 1997.

\section{Populist Strategy}

Founded by the young and "modernizing" generation from within the Islamic movement, the AKP introduced itself as a center-right conservative democratic party rather than a radical Islamic organization. Learning from the mistakes of their successor, to eliminate the risk of a new military intervention, the AKP did not adopt an anti-western rhetoric in pursuit of economic agreements with the Islamic states. Although it quickly adopted a conservative identity, it did not try to Islamize the society from above. While trying to rebuild the economy on a neoliberal base, which had collapsed with the financial crisis of 2001, the party got the approval of the bigger capital; they also aimed to gain the support of the poor commoners via social assistance policies (Koray \& Çelik, 2015; Özden, 2014; Yıldırım, 2010). The most important element of this neoliberal conservative hegemonic project lied in the populist strategy the party had adopted.

We use the term "populism" here as "to lean against the large segments of the population in order to establish one's own hegemony against the previous political powers" and "to make The 'us' against 'them' Language" absolute among this population by redirecting their heterogeneous reactions (political, economic, cultural) towards a rather vague 'elite' class. Generally, as seen in Latin American countries, a movement under the guidance of a charismatic leader presents itself as the representative of all people -the oppressed and poor- and claims that they make politics above all classes when they come to power; however the truth is hardly anything like they propose and they usually serve only to the interests of the capital (Löwy, 1987; Yalman, 1986).

According to Turkey's classic right populism, which was also adopted by the AKP, the underlying political polarization in Turkey historically was between the state and the nation "Millet". On the one hand there is the authoritarian, bureaucratic Kemalist power, which is alien to the authentic 
values of the nation, with its civilian supporters; on the other hand there are those who were religious but could not live their lives accordingly, since they were oppressed and despised by the Kemalist elite and also excluded from the power block. Just like center-periphery, state-society or bureaucratic powerbourgeoisie conflicts the dominant historiography in Turkey; State-nation conflict, which supports the conservative populism is also described in a relation of exteriority, and it relies on a rather essentialist dualism. A comprehensive critique of the above approach is no doubt beyond the scope of this article (Akça, 2006; Aydin, 2009; Dinler, 2003; Yalman, 2002). Two separate trends arose from this strategy:

1. The history of Turkey is filled with military coups, memorandums and martial laws. Although the nationalism and state fetishism among the Turkish society is shared by almost all the mainstream political tendencies; it was considered that the weight of the Turkish Armed Forces over politics was over in the 2000s. Within the framework of the political reforms demanded by the European Union in order for Turkey to have a full membership, the AKP adopted a common democratization rhetoric that would not frighten the military. However, the steps taken to control the state apparatus starting from 2007 faced the resistance from the military as well as the laicist social sectors, so the AKP shifted its rhetoric to a new anti military and bureaucratic tutelage regime based one. By receiving $46.5 \%$ of the votes that year the AKP presented itself as the representative of the "national will" which according to them, the tutelage regime was trying to suppress. But these practices were also justified in the name of maintaining democracy and the national will. During this period the authoritarianism became one of the main pillars of this populist hegemonic project with political mass trials, media pressure and new regulations concerning national security. While Kemalist -along with socialists and Kurdish- opposition was kept under pressure; in the name of protecting the national will and democracy, the authoritarian practices were once again justified as the precautions for a possible "state of emergency" such as a military coup.

2. Although they adopted democratic, rhetoric and economic policies that would guarantee the support of different fractions of society during their first ruling era, the party argued that the religious-conservative identity of Anatolia should be normalized in political, economic and cultural terms. The AKP took some measures and made sure the sections that form their base would not be seen as second-class citizens by the state anymore. The primary example was the legalization of wearing headscarves in university campuses. But starting from 2010, by making the military retreat and dominating the state apparatus, the party and the country entered to a new era where the Sunni-Islamic conservatism was being glorified and declared as the new "first class"; while the secular life-style (encoded within the term "White Turks") 
was being marginalized. In this regard, the policies that would blend the Islamic references in the public sphere and everyday life were adopted. Islamization of education, lifting the ban of wearing headscarf for women who are public servants and the ever-increasing references to religion in the politicians' discourses can be given as an example (Bora, 2014; Insel, 2012; Okçabol, 2013; Türk, 2014). Today the president Recep Tayyip Erdoğan carries out political rallies and swings a copy of the Qur'an he holds in his hand for propaganda purposes while making promises or accusing his rivals (2015 national elections).

\section{Authoritarian Populism vs. Social Media}

We need to examine the AKP's interventions on social media content and the use of social media tools in the context of this conservative populist strategy. We can discuss these interventions which saw an increase starting from 2007 until today in three main parts.

\section{Morally Right, Securely Tight}

In 2007, five years after its first election victory, the AKP which seemed to have secured its position, made its first major attempt to audit the online communication processes and the content available. The Presidency of Telecommunication and Communication (TIB), another governmental association founded during the AKP rule which has no autonomy and is directly connected to the Ministry of Transport, Maritime and Communication was given the authorization to regulate the internet and to restrict internet communication. In case of criminal activities prohibited by the new "Internet Law", courts would be the judicial authority and TIB could carry out the action it saw fit freely once a website was found guilty.

The law prohibits: encouraging suicide, facilitation of drug abuse, unauthorized online gambling and betting and providing a place or opportunity for such actions, crimes against Atatürk, offering or promoting prostitution, sexual abuse of children etc. Breaking the law in any way can cause any website to be blocked. However, a high amount of charges these websites face are related to sexually explicit content. Obscenity is a highly vague concept and it is open to interpretation. Defining it as a crime is problematic enough since every culture approaches it differently based on their beliefs and moral values but putting a government related institution in charge to decide about that clearly poses a threat to the freedom of expression (Gedik, 2008; Köse \& Özen, 2010; Özel, 2015).

According to the data from 2010 that TIB shows on its website, $70 \%$ of the blockings are "obscenity" related while a quarter of this figure covers the crimes related to the sexual abuse of children. TIB refuses to share its detailed statistics after 2010 with the public. On the other hand, it should be noted that the government is not alone in making demands for "An internet coincides with 
moral values". More than 500 thousand calls were made to TIB until April 2012 and $85 \%$ of them were again related to obscenity, prostitution and the sexual abuse of children (Avc1, 2013, 2015). It should also be emphasized that TIB's jurisdiction has been constantly expanding since 2007. Another law that was amended in 2014 gave the TIB further authority over the internet and removed the requirement to seek a court order prior to blocking websites. This meant that courts were not the only judicial authority anymore and for the first time ever, an association with direct relations to the government had the authority to make decisions that would restrict access to websites. In early 2015, premiership and some ministries were also given the authorization to block websites in addition to TIB and the law expanded covering even more cases. According to the latest data, so far until May 25, 201580.118 websites have been blocked in Turkey and $93.5 \%$ of them were blocked by TIB $^{1}$. TIB released and sent a list to hosting clients and service providers, that prohibits the use of a huge amount of words in domain names and that list alone is enough evidence to how arbitrary the decisions were. Besides various Turkish words, the list includes English words like "Adrianne, animal, beat, escort, fire, girl, homemade, free, gay, hot, partner, teen..." 2 .

Another major attempt to moralize the digital public sphere and intervene with free will on the internet was the highly controversial "Safe Internet" application that was introduced back in 2011. This application would make choosing a filter obligatory for every individual internet service subscriber. There were three kinds of filters: Standard, Family, and Kids with standard being "unsafe", while the other two were heavily promoted as "safe". It was still possible to access websites other than the ones that have already been blocked by TIB with the "unsafe" filter, while choosing Family or Kids would mean the restriction of unknown number of websites for entirely unclear reasons. The Internet Filter, which was being promoted as "Internet Profile" after raising some eyebrows was a rather paternalist approach and it proved that the government does not see its citizens as conscious and responsible human beings. The government clearly decides for them, but does not respect their decisions. Instead, the government and its officials and bureaucrats were deciding what is safe or not, based on their own understanding of "family", "morality" and "traditional values". People were cautious and nobody could predict what the extent of this filtering was since the law that is already in effect was restricting access to websites about Darwin and evolution, news agencies' the government disapproves, or even some official websites for labor and political unions. This shows how far one could go once the vague concepts like "family values", "mental and physical health of children" and "moral values" are added in the mix.

Thus the filtering faced an enormous negative reaction from people. It was declared as "The Death of the Internet" by millions of internet users, several professional organizations, NGOs, labor unions and political parties. Huge protests erupted all over the country including the major cities. Approximately

\footnotetext{
${ }^{1}$ http://goo.gl/3KSGAt. [Accessed: 25 May 2015]

${ }^{2}$ http://goo.gl/orH4ZB. [Accessed: 26 April 2015]
} 
20 thousand people took part in the demonstrations at Taksim Square in central Istanbul in which most young people take part in a street protest for the first time. As a result of the protests, some minor changes were made to the filtering application, -like using the word of profile, instead of filter- and it remained as an optional choice although choosing a "profile" was still obligatory. Still, it was a victory won mostly by the efforts of the young generation who had no links to unions, human rights organizations or left-wing political parties and they would show up once again two years later, in a series of events that would shake the whole country: Gezi Park Protests.

\section{Block the Access, Prevent the Coup}

Two separate and unpredictable turn of events shook the AKP's foundations in 2013. The first one, Gezi Resistance, was the result of a tension that had been building up slowly for several years and it emerged as a response to the AKP's authoritarian policies. It was and still is the biggest uprising the AKP has ever faced due to its results, the international media coverage it received and probably because of the widespread support it gained from the many different fractions of people in Turkey. It was also the very reason why the AKP had to make changes on its monitoring policies towards a more effective way. We can say that all of the above examples-restricting access to gambling websites, websites that contain obscenity related content, or that may suggest ideas other than the religion orders etc. were merely some means to achieve the sunni-Islamic way of life the AKP were trying to replace the secular life with. In this regard, they were all proactive measures against a more dormant nuisance on the way of achieving that goal, rather than being an imminent threat to the government's ruling position. The Gezi Resistance however, due to its unique characteristics -from the AKPs perspective- fast paced nature and its occurrence with no evident heads-up -it was only a very small, ordinary protest at the beginning- required the AKP's full attention and urgent reaction. The news about excessive police violence against a small, peaceful group of protesters whose only purpose was to save the park from becoming another shopping mall were all over the internet all of sudden. The mainstream media however did not cover the incident at all while it quickly turned into a snowball over the social media-especially on Twitter- and reached to millions just about in a single day. At least 2 million tweets were twitted on the first day of June, $2013^{1}$. Another interesting fact was that the content the users were sharing, talking about or using social media to spread it before and during the Gezi Resistance changed drastically. The data shows the sudden drop of mentions about a very popular TV show -Survivor- during that period on Twitter. While the show continues throughout the uprising, only 7.000 tweets were tweeted about it in June compared to nearly 45.000 tweets in $\mathrm{May}^{2}$. The flow of information on other channels was nonstop as well as with live streams, tweets, wiki pages, videos, pictures and news articles showing up

\footnotetext{
${ }^{1}$ http://goo.gl/9W3OjT. [Accessed: 10 September 2015]

${ }^{2}$ http://goo.gl/odbbNG.
} 
almost every minute. More and more people were being aware of the situation and taking part in the action as the uprising spread all over the country. The mainstream media mostly maintained its position by not giving any coverage if not to blame the protesters-, and became the subject of anger and mockery because of this ${ }^{1}$.

The second major blow came later that year. The Gezi crisis reached a critical threshold so that it caused cracks on the power block itself and put the AKP in another tight spot. Secretly infiltrating the state bureaucracy -mainly the police and the legal system- since the eighties and organized in these networks, the Gülen Movement had been the AKP's strongest ally in its fight against the Kemalist-secular bureaucracy; although, it was commonly known that they had already been having conflicts over various political and organizational matters for some time. The separation between the Gülen Movement and the AKP showed its first signgs with the Mavi Marmara massacre. The Mavi Marmara ship which was carrying aid to Gaza, which was under the Israeli blockade was attacked by Israeli commandos and nine people on board were killed. Always trying to establish good relations with the West, Gülen Movement condemned Turkey for not settling things with Israel and sparked the first crisis.

Conflicts about the Kurdish problem, one of the most important issues in Turkey for democratization, also surfaced in the mean time. The MIT (National Intelligence Organization) undersecretary who met with the PKK leaders in Oslo, on the behalf of the Turkish government, was called for a testimony by the prosecution under the suspicion of treason without the government's knowledge. Prime Minister Erdoğan personally prevented such an action and the crisis expanded. Taking a more democratic approach this time during the Gezi Resistance compared to the AKP's authoritarianism, Gülen Movement and its media organizations intensified the breach. Thus the government made another controversial attempt and decided it was time to close all the private classrooms and shut down all kinds of supportive educational activities in order to kill the Gülen Movement's financial resources and their chance to be organized in these institutions. This dramatic turn of events caused a major disturbance among people as it was not only affecting the Gülen Movement's foundations but also all the schools throughout the country as well. That meant that approximately five thousand schools were to be shut down and 50 thousand people would lose their jobs. Nevertheless, the government did not step back and this decision proved the bridges were burned. But it was during December of 2013 when the definitive rupture occurred. Children of the AKP's ministers and some businessmen were taken into custody accused of corruption as the result of a criminal investigation by the prosecutors and the police officers connected to the Gülen Movement. Prime Minister Erdoğan stopped the investigation as it was just about to involve him and his family as well. Thereupon, tapes that involve Erdoğan and his family, ministers and businessmen began to leak which were presumably recorded secretly by the Gülen Movement's officials in the state (Ş1k, 2014; Sönmez, 2014).

\footnotetext{
${ }^{1}$ http://goo.gl/76Z6vj. [Accessed: 10 September 2015]
} 
Some of them were particularly worth noting: On one tape, Erdoğan was directing his son to move a huge amount of money stashed in their house. On another, Erdoğan was clearly controlling the content on TV channels -even intervening in some cases like manipulating poll results in favor of his party. Another one revealed that in order to carry out an operation in Syria, the national intelligence organization was getting ready to have their agents in Syria fire missiles to Turkey.

The AKP defined the Gezi Resistance and their closest ally's betrayal as a plot and a coup attempt: A plot that brought both the international powers and the Kemalist-republican fractions together working against the government. Thus they articulated these two events to the anti-coup discourse of their conservative populist hegemonic project as they promoted it as a deeply designed malicious plan; though they had to call it "Civilian Coup" since neither the Gezi Protesters nor the members of the Gülen Movement had any connections to the armed forces.

The AKP quickly took some measures against this "Civilian Coup Attempt". Blocking access to social media platforms that were spreading the tapes, just like they were spreading the news during the Gezi Resistance, was on top of that list. Erdoğan showed his determination in the rallies. He claimed sharing stuff had nothing to do with freedom. He said "he would not let his nations be devoured by Youtube or Facebook and hinted a restriction that was not so far away". In another speech he said "Twitter Schmitter... We will wipe them all out. The international community can say this, can say that. I don't care at all. Everyone will see how powerful the Republic of Turkey is"1. The day after this speech, Twitter was blocked for 14 days. Court orders based on violations of personality rights and the private life were cited as the reason. One week after Twitter, Youtube was also blocked for a month due to some videos uploaded about the conspiracy involving Syria. These were considered as a "primary threat against the national security". Blocking Youtube is not really a new phenomenon for Turkey. The website was blocked several times in the past since 2007 and in 2008 it actually lasted longer than 2.5 years. Although the website was down in Turkey due to some videos insulting Atatürk, Erdoğan, at that time, said mockingly and referring to alternative ways of access: "I can access, so do you, too." But the time to recommend people to show democratic disobedience against the state's prohibiting practices had clearly passed. Now there was a government which became the state itself, and it was time to defend itself with prohibitions.

\footnotetext{
${ }^{1}$ http://goo.gl/bJsp6N [Accessed: 22 May 2015], http://goo.gl/bHOLI6 [Accessed: 22 May 2015], http://goo.gl/9ms7lV [Accessed: 24 May 2015].
} 


\section{Follow on Twitter, Try in Court}

The referendum held on September 12, 2010 which aimed to make some changes in the constitution, promised some steps further towards democratization, such as prosecuting those responsible for the military coup of September 12, 1980 and lifting the tutelage power over the legal system. Receiving $58 \%$ of the votes and widespread support, the referendum caused authoritarianism rather than democratization contrary to what most people hoped. Although freed from the traditional Kemalist tutelage regime, the judicial apparatus was now under the control of the executive branch, namely a political party. With a range of tactics such as political arrests, control over the media, marginalization of the secular lifestyle, the oppressive and the excessively protective side of the state under the AKP government showed itself. Another major step towards a more authoritarian state architecture and the building of a "police state" was taken by passing the new internal security legislation after the incidents such as Gezi Protests and Kobane Incident -a Kurdish city which the AKP refused to help during the time it was under the siege of ISIS- where 50 people died (Aydın, 2015; Berksoy, 2012; Göktaş, 2014).

Neither the shocking network of dark relations revealed during the corruption investigations, nor the fact that 10 people had already died because of excessive police violence during and after Gezi Protests could make Erdoğan step back. His hostile behavior put him in the center of all the hatred. "Thief, Murderer Erdoğan" became the primary slogan for all protests. However, these two words are now regarded as a serious crime. "Insulting the president", a very rarely referred article in the Turkish Penal Code before Erdoğan, was now being operated excessively to punish anyone who criticize Erdoğan in any way. People have been questioned, investigated or taken into custody after their homes were raided by the police ${ }^{1}$. Some of them were fined or arrested almost immediately. Although Erdoğan called social media "a menace to society" during the Gezi Protests, we can assume that these platforms are highly convenient for detecting "rebels" and punishing them when the opportunity arises.

We saw 60 Twitter accounts being investigated in the first three months of 2015, and among them were journalists, famous people and even some deputies from opposition parties ${ }^{2}$. We will only give a few examples: An anchorman from a TV channel with relations to the Gülen Movement faced 8 years in prison for insulting the president. A 15 year old high school student was sued for the same reason. An LGBT activist was fined for tweeting a gay

\footnotetext{
1 http://goo.gl/pdmmN0. For some examples: http://goo.gl/mMDTz0, http://goo.gl/iCuZSs, http://goo.gl/sRJDBx, http://goo.gl/b7DMPV, http://goo.gl/9Oya8J.

${ }^{2}$ http://goo.gl/8H0aEg. [Accessed: 25 May 2015].
} 
joke about Erdoğan. A member of the main opposition party was also arrested for criticizing Erdoğan and the AKP on Facebook ${ }^{1}$.

\section{Conclusions}

Succeeding to establish an inclusive hegemony by promising to end military tutelage and democratization, the AKP only tried to have an absolute control over the state apparatus, in order to consolidate its power. When they faced opposition and tried to suppress it, they had to adopt a narrower project: A project whose main pillars were based on an authoritarianism that even ignores the separation of powers, and a populism that clearly has an Islamic character. If the AKP had succeeded to receive enough votes in the elections of June 2015 that would give them the power to govern Turkey alone, like they did over the past decade since 2002, they were planning to establish a new state design in Turkey by creating a brand new constitution. The project which the president Recep Tayyip Erdoğan was fanatically promoting was predicting the transition to an autocratic presidential regime where even the basic principles of parliamentary democracy would be thrown away.

Creating a significant opportunity for public debate, participation and the freedom of expression, the internet is an important public sphere. The policies and the measures concerning the Internet that we summarized above can be seen as the indications of what this state project could have brought with it. The election results did not give the AKP an opportunity to create such a state design all by itself and gave four separate political parties the chance to be present in the next parliament instead, also they proved that there is indeed a national will in Turkey, but it does not need to be protected by authoritarian practices like the AKP would like people to believe. On the contrary, it demands more freedom, democracy and clearly pluralism; and the Gezi generation who was organized on social media during this period, no doubt, had a profound impact on this outcome. They spread reliable information and eliminated false government propaganda. They protected the votes they cast by monitoring the whole election process closely, from start to finish, in order to prevent and report possible electoral fraud, which happened frequently in the past; and they shaped their future against all odds.

\section{References}

Akça, I. (2006). Militarism, Capitalism and the State: Putting the Military in its Place in Turkey (Unpublished doctoral dissertation). Boğaziçi University, Istanbul.

Akça, I. (2009). The articulation(s) and disarticulation(s) between militarism and capitalism in the age of neoliberalism: The case of Turkey in the post-1980

\footnotetext{
${ }^{1}$ See the links for the news: http://goo.gl/aS9mq3 [Accessed: 27 April 2015], http://goo.gl/K8 dH4A [Accessed: 26 April 2015], http://goo.gl/dui9Ko [Accessed: 26 April 2015], http://goo. gl/jTqR7V [Accessed: 27 April 2015].
} 
period. Militarism: Political Economy, Security, Theory. Centre for Global Political Economy, University of Sussex, Brighton.

Akça, I. (2010). Ordu, Devlet ve Sınıflar: 27 Mayıs 1960 Darbesi Örneği Üzerinden Alternatif Bir Okuma Denemesi [The Military, the State and Classes: An alternative Study Essay Over the Case of the Coup of May 27, 1960]. In. E. Balta Paker \& I. Akça (Eds.), Türkiye'de Ordu, Devlet ve Güvenlik Siyaseti [The politics of Military, State and Security in Turkey]. Istanbul: Istanbul Bilgi Üniversitesi Yayınları.

Akça, I., Bekmek, A, \& Özden, B. A. (2014). Introduction. In. I. Akça, A. Bekmen, \& B. A. Özden (Ed.), Turkey Reframed. Constituting Neoliberal Hegemony. London: Pluto Press.

Avcı, A. (2015). İnternetin 'Ahlakî' Kamusal Alanı ['Moral' Public Sphere of the Internet]. In U. Uraz Aydin (Eds.) Neoliberal Muhafazakar Medya [Neoliberal Conservative Media]. Istanbul: Ayrinti.

Avc1, A. (2013). Türkiye'de Internet ve Ifade Özgürlüğ̈̈ [The internet and the Freedom of Expression in Turkey]. Istanbul: Legal yay.

Aydın, O. (2015). İ̧̧ Güvenlik Yasa Tasarısı: Anayasal Düzene Son [Internal Security Bill: An end to the Constitutional Order]. Retrieved from http://goo.gl/TWbh34. [Accessed: 20 January 2015].

Aydin, U. U. (2009). Gauches, Libéralisme et Démocratie. Les Mutations des Intellectuel Turcs - 1980-2008 [Left, Liberalism and Democratie. The Transformations of Turkish Intellectuals - 1980-2008] (Unpublished doctoral dissertation). INALCO/Marmara Üniversitesi.

Balta Paker, E. (2010). Dış Tehditten İç Tehdide: Türkiye'de Doksanlarda Ulusal Güvenliğin Yeniden İnşası [From the External Threats to the Internal: The Reconstruction of National Security in the 90s Turkey]. In E. Balta Paker \& I. Akça (Eds.), Türkiye'de Ordu, Devlet ve Güvenlik Siyaseti [The politics of Military, State and Security in Turkey] (pp. 407-431). İstanbul: İstanbul Bilgi Üniversitesi Yayınları.

Berksoy, B. (2012). Güvenlik Devleti'nin Ortaya Çıkışı, 'Güvenlik' - Eksenli Yönetim Tekniğinin Polis Teşkilatındaki Tezahürleri ve Süreklileşen 'Olağanüstü Hal': AKP'nin Polis Politikaları [The Emerging of the 'Security State' - The manifestations of 'Security' Centered Government Technique in Police Organization and the Ongoing 'State of Emergency': The AKP's policies on the Police]. Birikim No: 276, April 2012.

Bora, T. (2014). Muhafazakâr ve İslamcı söylemde Beyaz Türk hıncı: Beyaz Türk'e kahretmek [Hatred Towards White Turks in Conservative and Islamist Discourse: Damning White Turks]. Birikim No: 305, September 2014.

Boratav, K. (2005). 1980'li Yıllarda Türkiye'de Sosyal Sinıflar ve Bölüşüm [Social Classes and Distribution in Turkey in the 1980s]. Ankara: İmge.

Çoban, B. (Eds.). (2014). Sosyal Medya Devrimi [Revolution of Social Media]. Istanbul: Su Yayınlar1.

Della Porta, D. \& Tarrow, S. (Eds.). (2005). Transnational Protest \& Global Activism. Rowman \& Littlefield Publishers.

Dinler, D. (2003). Türkiye'de Güçlü Devlet Geleneği Tezinin Eleştirisi [The Critique of the Strong State Tradition's Thesis in Turkey]. Praksis No: 9.

Gedik, Ö. (2008). Türkiye'de Internet Özgürlüğü ve 5651 Sayılı Kanun [The Internet Freedom in Turkey and the Law no. 5651). Marmara Üniversitesi Hukuk Fakültesi Dergisi. Retrieved from http://goo.gl/sLwG1V. 
Gerbaudo, P. (2014). Twitler ve Sokaklar. Sosyal Medya ve Günümüzün Eylemciliği [Tweets and the Streets: Social Media and Contemporary Activism]. İstanbul: Agora.

Göktaş, K. (2014). Bir Savaş Hazırlı̆̆ı olarak 'Güvenlik' Paketi ['Security Bill' as a War Preparation]. Retrieved from http://goo.gl/4CF7Bz. [Accessed: 21 October 2014].

Insel, A. (2012) Güven Tesisinden Özgüven Patlamasına [From Assurance to Presumptuous]. Birikim No: 283, November 2012.

Jessop, B. (2008). Devlet Teorisi: Kapitalist Devleti Yerine Oturtmak [State Theory: Putting the Capitalist State in its place]. Ankara: Epos.

Koray, M. \& Çelik A. (Eds.). (2015). Himmet, Fitrat, Piyasa. AKP Döneminde Sosyal Politika [Aid, Creation and Market. Social Policies During the AKP Government]. Istanbul: İletişim.

Köse, G. \& Özen, K. (2010). İnternet’te Sansür Üzerine Bir Değerlendirme [An Evaluation of Censorship on the Internet]. Uluslararası Değişen Dünyada Bilgi yönetimi sempozyumu [The Second International Information Management in a Changing World Symposium]. Hacettepe Üniversitesi. Retrieved from http://goo.gl/eqQVhk.

Löwy, M. (1987). Le populisme en Amérique Latine [Populism in Latin America]. Amsterdam: Institut International de Recherche et de Formation.

Okçabol, R. (2013). AKP İktidarında Eğitim [Education during the AKP Rule]. İstanbul: Ütopya.

Öngen, T. (2002). Political Crises and Strategies for Crises Management: From 'Low Intensity Conflict' to a Regime of Low Intensity Instability. In N. Balkan \& S. Savran (Eds.), The Politics of Permanent Crises, Class, Ideology and State in Turkey. New York: Nova Scientific Publishers.

Özden, B. A. (2014). The transformation of Social Welfare and Politics in Turkey: A Successful Convergence of Neoliberalism and Populism. In I. Akça, A. Bekmen \& B. A. Özden (Eds.), Turkey Reframed. Constituting Neoliberal Hegemony. London: PlutoPress.

Özel, C. (2015). 5651 Sayılı İnternet Ortamında Yapılan Yayınların Düzenlenmesi ve $\mathrm{Bu}$ Yayınlar Yoluyla İşlenen Suçlarla Mücadele Edilmesi Hakkında Kanun Üzerine Düşünceler [The Thoughts on the Law no. 5651 of Regulation of Electronic Publications and Preventing the Crimes Commited by Them]. Retrieved from http://goo.gl/w0TmFo. [Accessed: 23 May 2015].

Özkazanç, A. (2005). Türkiye'nin Neo-Liberal Dönüşümü ve Liberal Düşünce [NeoLiberal Transformation of Turkey and Liberal Thought]. Modern Türkiye'de Siyasi Düşünce. Liberalizm [Policital Thought in Contemporary Turkey. Liberalism] (pp.634-656). İstanbul: İletişim.

Şık, A. (2014). Paralel Yürüdük Biz Bu Yollarda. AKP-Cemaat İttifakı Nasıl Dağıldı? [Our Parallel Paths: How the AKP-Cemaat Allience Was Broken]. İstanbul: Postac1.

Sönmez, M. (2014). AKP-Cemaat. Çatışmadan Çöküşe [AKP-Cemaat. From Conflict to Collapse]. Ankara: Nota Bene.

Tufekci, Z., Wilson, C. (2012). Social Media and the Decision to Participate in Political Protest: Observations From Tahrir Square. Journal of Communication, 62(2), pp. 363-379.

Türk, H. B. (2014). Muktedir. Türk Să̆ Geleneği ve Recep Tayyip Erdoğan [Turkish Right Tradition and Recep Tayyip Erdoğan]. Istanbul: İletişim.

Van De Donk, W., Loader, B. D., Nixon, P. G. \& Rucht D. (Eds.). (2004). Cyberprotest. New Media, Citizen and Social Movements. London: Routledge. 
Yalman, G. (2002). The Turkish State and Bourgeoisie in Historical Perspective: A Relativist Paradigm or a Panoply of Hegemonic Strategies. In N. Balkan \& S. Savran (Edn.), The Politics of Permanent Crisis. Class, Ideology and State in Turkey. New York: Nova Science Publishers.

Yalman, G. (1986). 'Popülizm', 'Bürokratik Otoriter Devlet' ve Türkiye ['Populism', 'Bureaucratic Authoritarian State' and Turkey] 11. Tez No: 1.

Yıldırım, D. (2010) AKP ve Neoliberal Popülizm [AKP and Neoliberal Populism]. In I. Uzgel \& B. Duru (Edn.), AKP Kitabı: Bir Dönüşümün Bilançosu [AKP Book: The Aftermath of a Transformation]. Ankara: Phoenix. 
